\title{
Skuffelse i Frankrig
}

Connie Pedersen

\section{Præsidenter kommer og går, men problemerne består. Det må Frankrigs nye præsident sande, og i Frankrigs tilfælde hedder problemerne først og fremmest arbejdsløshed og kriminalitet}

François Hollandes forgænger Nicolas Sarkozy var 'for meget' - for udfarende, for energisk og for aggressiv. Hollande er 'for lidt' - for lidt synlig, for slap og for passiv. Det er den tone, de franske medier har slået an, og deres skuffelse afspejler sig i meningsmålingerne. Et halvt år efter at Hollande blev valgt, har under halvdelen af franskmændene tillid til, at den nye socialistiske præsident kan løse landets problemer.

Efter franske forhold er det meget lavt så kort tid inde i en embedsperiode, og Hollandes eneste trøst er, at et flertal af vælgerne ifølge meningsmålingerne heller ikke tror, at den borgerlige opposition kan gøre det meget bedre. Hverken præsidentens ellers regeringens politiske liv er på nogen måde i fare, men franskmændene er utålmodige og modløse.

Det er helt normalt for franske præsidenter, at deres 'hvedebrøds- dage' med vælgerne får ende. "Nyd det, for det varer ikke ved", advarede François Mitterrand i sin tid sine folk, og han var endda en af de franske præsidenter, der klarede overgangen fra kandidat til præsident bedst. Et år efter at han var blevet valgt i 1981, scorede han stadig højt på tillidsbarometeret. Så længe har Hollandes 'hvedebrødsdage' ikke varet. Der har stort set ikke været nogen. Allerede da Hollande vendte hjem fra ferie i slutningen af august - tre måneder efter at han var blevet valgt - var hans popularitet faldet ned under de 50 pct., og nu ligger den nærmere de 40 pct.

Vælgerne synes, at Hollande og hans regering er for passiv i forhold til den $\varnothing$ konomiske og sociale krise, landet befinder sig i. Spørgsmålet er, hvor vælgerne har fået den opfattelse fra. USA's præsident, Barack Obama, har sagt, at en politiker er den, som medierne siger. Direktø- 


\section{BAGGRUND}

ren for et af de franske meningsmålingsinstitutter er inde på det samme. Han peger på, at medierne fra starten kastede sig ud i en voldsom 'Hollande-bashing', en medie-mobning, der trækker læsere til aviskioskerne og formentlig også påvirker deres syn på landets øverste leder.

Som det første lagde det borgerlige ugemagasin Le Point ud med skarp kritik af den nyvalgte præsident. Det afspejlede sig både i artikler, ledere og især forsiderne. En af bladets første forsider efter valget viste Hollande i blæsevejr med håret $\mathrm{i}$ vild uorden. "On arrête avec les bêtise?" (Er man snart færdig med tåbelighederne?) stod der hen over forsiden, og det fik salget i bladkioskerne til at stige fra 85.000 til 115.000 eksemplarer. Lige efter sommerferien bød ugebladet Hollande tilbage til arbejdet med ordene "On se réveille?" (Er man ved at vågne op?).

Siden fulgte det andet borgerlige ugeblad L'Express trop. Det var hård ved Sarkozy, da han var præsident, men i august 2012 havde det en forside med en meget alvorlig og tænksom Hollande, og over hans ansigt stod "Et si Sarkozy avait eu raison?" (Og hvad nu hvis Sarkozy havde ret?). Den forside gav et mersalg på 20.000 eksemplarer.

Nok så opsigtvækkende er det, at de venstreorienterede ugemagasiner Marianne og Le nouvel Observateur har anlagt samme anti-Hollande linje. Le nouvel Observateur spurgte på sin forsiden i slutningen af august $\mathrm{i}$ år "Sont-ils si nuls" (Er de så dumme?) hen over et billede af den socialistiske præsident sammen med sine ministre foran Elysée-palæet. Det var en forside, der havde været megen debat om på redaktionen $\mathrm{og}$ i bladets ledelse. Man havde også overvejet at skrive "La déception" (Skuffelse) eller "Les amateurs" (Amatørerne).

Chefredaktøren forklarede, at han ikke anså Hollandes hold for at være tåber, men de var efter hans mening alt for langsomme, når det gjaldt reformer og udspil. "Hollande secoue-toi, il y a le feu" (Kom op i omdrejninger Hollande, det brænder). Sådan stod der på forsiden af det ret så venstreorienterede Marianne $\mathrm{i}$ slutningen af august. Bladets chefredaktør forsikrede dog, at bladet stadig støtter Hollande.

Når der er en klangbund for mediernes kritik, hænger det sammen med den økonomiske og sociale krise, Frankrig står i. Det altoverskyggende problem er arbejdsløsheden, der selv i gode tider har været mærkbart højere i Frankrig end i de andre gamle EU-lande. Det hænger sammen med det franske arbejdsmarkeds særlige indretning.

\section{Arbejdsløshed}

PSA-bilkoncernen, der fremstiller Peugeot- og Citroën-biler, er kronjuvelen i den franske bilindustri, så det vakte kolossal opsigt, da firmaet kort før sommerferien 2012 meddel- 
te, at det blev nødt til at afskedige 8.000 medarbejdere, heraf 3.000 på bilfabrikken i Aulnay uden for Paris, der skulle lukke helt. Firmaet sælger ikke biler nok, og det havde de ansatte godt fornemmet, men alligevel kom meddelelsen om massefyringerne som et chok.

Den franske industri i det hele taget og bilindustrien i særdeleshed har det svært, for deres produktionsomkostninger er meget høje, og det går ud over konkurrenceevnen.

De truende afskedigelser i PSAkoncernen blev den nye socialistiske regerings første store udfordring på det anspændte arbejdsmarked, og der blev straks rejst krav om, at staten skulle gribe ind og forhindre fyringerne. I Hollandes første store tvinterview som præsident - $i$ anledning af den franske nationaldag 14 . juli - blev han igen og igen spurgt, hvad han ville gøre for at redde de truede arbejdspladser. Hans svar var vage, og overbeviste ikke de fyringstruede. Han sagde, at han ikke kunne acceptere masseafskedigelserne, men det endte han alligevel med at gøre et par måneder senere.

I forvejen er køen af arbejdsløse lang. Den passerede i oktober den triste grænse på tre millioner arbejdsløse eller godt 10 pct. af arbejdsstyrken. Der er tre væsentlige grunde til, at så mange franskmænd står uden arbejde. Den første er den generelle økonomiske krise, som har ramt især de sydeuropæiske lande hårdt. Den betyder, at virksomheder lukker, indskrænker og afskediger. Den anden grund er, at Frankrig er et af de lande i Europa, der får flest børn, og det betyder, at der hvert år er rigtig mange unge, der søger ind på arbejdsmarkedet - flere end der er ældre, der forlader det.

Den tredje grund er, at det franske arbejdsmarked er meget stift. Det er svært at fyre en ansat, derfor er virksomhederne tilbageholdne med at ansætte folk, også i gode tider, for de er bange for, at de ikke kan fyre medarbejderne igen, hvis det bliver dårlige tider. For at komme uden om problemet ansætter mange virksomheder folk på midlertidige kontrakter. Der har været gjort flere forsøg på at gøre det franske arbejdsmarked mere smidigt. Flere franske politikere har været tiltrukket af den danske eller den skandinaviske model. Den giver lettere adgang til at fyre ansatte, men til gengæld er der et netværk af omskoling, jobanvisning osv., der skal sikre, at folk kommer i arbejde igen.

Men den danske model lader sig ikke umiddelbart overføre til det franske arbejdsmarked, som har en anden struktur end det danske. I Danmark er det arbejdsmarkedets parter - fagforeningerne og deres modpart, arbejdsgiverne - der aftaler de regler, der gælder for arbejdsmarkedet. Staten blander sig meget lidt, til gengæld betaler den arbejdsløshedsunderstøttelse. I Frankrig derimod er det gennem trepartsforhandlinger mellem regering, fagfor- 
eninger og arbejdsgivere, at arbejdsmarkedet reguleres. Det hænger sammen med, at fagforeningerne i Frankrig er meget svage. Kun ni pct. af de franske lønmodtagere er medlem af en fagforening mod cirka 80 pct. i Danmark.

Det var karakteristisk, at et af præsident Hollandes første større politiske tiltag var at indkalde til et stort anlagt todagesmøde mellem arbejdsmarkedets parter og regeringen $\mathrm{i}$ juli 2012.

\section{Hollande i omdrejninger}

"Lad os ikke fortryde, at vi stemte på dig", stod der på det banner, som en kvinde holdt op foran præsidenten, da han kom til byfest i Châlons-en Champagne i Nordfrankrig for at holde sin første store tale efter sommerferien. Stemningen var alt andet end sommerlig, og det virkede som om Hollande havde taget kritikken af hans første 100 dage alvorligt.

For første gang siden han blev præsident, valgte Hollande at sige det, som det er: "Den økonomiske krise er meget alvorlig"! For at afbøde krisens værste følge - den stigende arbejdsløshed - aktiverede han tidligere end planlagt to af sine valgløfter og lancerede dem som lovforslag: de såkaldte fremtidsjob og de såkaldte generationskontrakter.

Fremtidsjobbene er specielt rettet mod svage unge uden uddannelse i de fattige forstæder eller på landet. Staten tilbyder at betale to tredjedel af lønnen, hvis en kommune, et amt eller en lokal forening kan finde et job til en udsat ung. Dem var der ca. 500.000 af i Frankrig i 2011, og det er regeringens håb, at der hvert år kan skaffes 100.000 fremtidsjob til de meget dårligt stillede unge.

Det andet initiativ - generationskontrakterne - er rettet bredere til alle virksomheder i landet. De bliver bedt om at ansætte en ung mellem 15 og 24 år og samtidig beholde en ældre medarbejder over 57 år indtil pensionsalderen. For virksomheder med under 300 ansatte er ordningen frivillig, men for virksomheder med over 300 ansatte er den obligatorisk. Hvis en virksomhed ikke indgår generationskontrakter, mister den nogle af sine skattefordele.

Generationskontrakterne skal være med til at løse det dobbelte problem på det franske arbejdsmarked, at de unge har svært ved at komme ind på arbejdsmarkedet, og de ældre bliver smidt for tidligt ud af det. Ordningen er beregnet til at skabe 100.000 ekstra job om året $i$ fem år og samtidig fastholde et tilsvarende antal ældre i arbejde.

Begge ordninger, der skal træde i kraft i 2013, kommer til at koste penge. Fremtidsjobbene skønnes at koste to milliarder euro og generationskontrakterne to til tre milliarder om året. I forvejen er den franske statskasse slunken, og for at få penge til sine reformer og til at nedbringe landets meget store gæld kommer Hollande og hans regering 
ikke uden om at forhøje skatterne, og det er de rigeste, der skal betale mest.

\section{Millionærskat}

Det affødte et ramaskrig blandt de rigeste, da Hollande under valgkampen sagde, at velhavende franskmænd skulle af med 75 procent $i$ skat af det, de tjente ud over en million euro om året, hvis han blev præsident. Det valgløfte står han fast på, også selv om nogle af de mest velstående forretningsmænd, kunstnere og sportsstjerner har truet med at slå sig ned i Belgien eller Schweiz for at undgå at komme af med så mange penge til staten.

En af rigmændene har faktisk bedt om belgisk statsborgerskab. Det drejer sig om Frankrigs rigeste og verdens fjerde rigeste mand, Bernard Arnault fra LVMH-gruppen, der bl.a. ejer Christian Dior og Louis Vuitton. Han afviser selv, at han flygter i skattely og siger, at han ønsker at have dobbelt fransk-belgisk statsborgerskab, og at han stadig vil betale skat i Frankrig.

Millionærskatten er bare et af elementerne i socialisternes første finanslov - finansloven for 2013 som er blevet kaldt den barskeste i 30 år. Den rummer besparelser på 10 milliarder euro, skattestigninger for virksomhederne på andre 10 milliarder euro og endelig 10 milliarder i øgede skatter fra private. I alt 30 milliarder euro. Det er regnin- gen for at få underskuddet på statens budget ned på tre procent af bruttonationalproduktet.

Det er det mål, EU-landene har sat sig for 2013, og for Frankrig er det helt nødvendigt at få underskuddet på statens finanser og dermed også landets kæmpe gæld bragt ned. Frankrig har en statsgæld på 1.800 milliarder euro, eller hvad der svarer til 90 procent af bruttonationalproduktet. Hvert år betaler landet 50 milliarder euro til sine kreditorer. Det svarer til 13 pct. af statsbudgettet, og de penge ville regeringen meget hellere bruge til andre formål fx at få folk ud af de sociale problemer, som kendetegner mange af de store byers forstæder.

I de første ni måneder af 2012 blev 18 mænd dræbt i Marseille i bandeopgør, der har forbindelse til narkohandel. I eftersommeren i år blev situationen så alvorlig, at borgmesteren i en af de hårdest ramte bydele i Marseille foreslog, at militæret skulle gribe ind.

Marseille er den alvorligste udfordring, den socialistiske regering står overfor, når det gælder lov og orden, men der er også andre. I en af de fattige forstæder til Grenoble blev to unge mænd i oktober overfaldet af 10-15 jævnaldrende og stukket ihjel efter nogle småskænderier. I de fattige forstæder til Paris ulmer vreden, og den mindste gnist kan få den til at bryde ud.

Lov og orden er en mærkesag for de borgerlige partier i Frankrig, og 
Hollandes forgænger Sarkozy havde det som første prioritet. Inden Sarkozy blev præsident, var han indenrigsminister og dermed ansvarlig for politiet, og han var stolt af at blive kaldt 'Frankrigs strisser nummer et'.

Venstrefløjen bliver til gengæld tit beskyldt for at være blødsøden over for de kriminelle, så da Hollande kom til og skulle besætte posten som indenrigsminister, var det vigtigt for ham at finde en mand, der var tilstrækkelig barsk til, at han kunne afparere de borgerliges kritik. Den mand fandt Hollande i Manuel Valls, en yngre politiker af spansk oprindelse, der har været borgmester i en af de belastede forstæder til Paris. Han er blevet kaldt venstrefløjens Sarkozy, og han er så meget en 'lov og orden mand', at nogle af hans partifæller synes, han går for vidt, fx når han uden nåde smider romaer ud af landet.

I sagen om narkoopgørene i Marseille afviste Valls dog nødråbet om at sætte militæret ind. Han vil gå grundigere til værks og sætte ind med uddannelse, arbejde og bedre sociale vilkår. Men myndighederne er oppe mod nogle livsvilkår i Marseille, som gør deres kamp næsten håbløs. I de nordlige forstæder i Middelhavsbyen er 25 procent arbejdsløse, og i gruppen af unge under 25 år er hver anden uden arbejde. Så er en indbringende karriere som narkohandler fristende. En narkobande skønnes at kunne tjene titusindvis af euro om dagen. Til gen- gæld er arbejdslivet kort. På fire år er 80 mennesker blevet myrdet, og der har været 150 mordforsøg i den svært bevæbnede narkoverden i Marseille.

Tilmed viser det sig nu, at politiet i den meget belastede nordlige del af Marseille formentlig har været dybt involveret i narkoverdenen. I efteråret blev syv betjente anholdt, efter at det var kommet frem, at de havde afpresset narkohandlerne både for narko og penge.

Helt så blodigt som i Marseille går det ikke for sig i de parisiske forstæder, men den onde cirkel er den samme som i Middelhavs-havnebyen: arbejdsløshed, dårlige boligforhold, social nød og kriminalitet og narkohandel. Vreden mod omverdenen er kolossal, og en 'varm' augustnat 2012 i Paris-forstaden Amiens viste, at der kan bryde uroligheder ud med meget kort varsel, ligesom det skete i 2005.

Dengang - i 2005 - blev forstæder overalt i Frankrig sat i brand efter et sammenfald af uheldige omstændigheder. I sin egenskab af indenrigsminister havde Sarkozy besøgt den fattige Paris-forstad Argenteuil, og her havde han kaldt kriminelle indvandrere racaille, 'noget rakkerpak'. Nogle måneder forinden havde han sagt, at han ville højtryksspule, nettoyer au Kärcher, Parisforstaden Courneuve, så den blev renset for narkoforbrydere. Det skete efter, at en 10årig dreng var blevet dræbt under en skudveksling mellem rivaliseren- 
de indvandrerbander, mens han stod og vaskede sin fars bil.

Sarkozys udtalelser, der i deres grove sprogbrug var usædvanlige for en minister, kom til at virke som ild, der blev sat til en krudttønde, da to indvandrerdrenge fra en anden forstad blev dræbt et par dage senere, da de kravlede op i en transformatorstation under en flugt fra politiet.

Det tændte en eksplosion af vrede først i de fattige parisiske forstæder og derefter i forstæderne til andre storbyer. Her brændte de unge 10.000 biler og 30.000 skraldespande af på tre uger. Hundredvis af skoler, posthuse og forretninger blev sat i brand, og i alt blev der ødelagt værdier for 200 mio. euro.

Så galt gik det ikke i Amiens i august 2012, men det var alvorligt nok. Baggrunden var, at en ung mand var blevet dræbt i en trafikulykke, og hans familie og venner ville gennemføre en tavs sørgemarch i forbindelse med begravelsen. Politiet var til stede for at regulere trafikken, og betjentene optrådte unødigt aggressivt, mente sørgemarchens deltagere, så det endte med sammenstød mellem politiet og omkring 100 unge mennesker. 17 betjente blev såret, en børnehave og et par offentlige bygninger blev brændt ned, og der blev sat ild til biler, og ødelæggelserne blev gjort op til flere millioner euro.

Det var indenrigsminister Valls' første styrkeprøve med uromagerne i de parisiske forstæder. Han satte hårdt mod hårdt og sendte et massivt opbud af politi af sted til Amiens med det resultat, at uroen stoppede lige så pludseligt, som den var begyndt. Som en mere langsigtet løsning har Valls erklæret 15 områder for særlige sikkerhedszoner, Zone de sécurité prioritaire, ZSP. Her er det planen at gøre en ekstra indsats socialt og politimæssigt for at komme narkohandelen til livs og forbedre de sociale vilkår. En af de zoner er Amiens.

Urolighederne i Amiens har fået som konsekvens, at Valls har taget et omstridt forslag af bordet, et forslag om at de unge i forstæderne skulle have en kvittering, når de blev standset af politiet, så de undgik at blive visiteret flere gange om dagen, sådan som de tit kommer ud for. Forslaget var blevet kritiseret og latterliggjort af de borgerlige som et knæfald for de unge kriminelle. Da indenrigsministeren skrottede det, blev hans egne partfæller til gengæld vrede og beskyldte ham for at være for streng. Men generelt anerkender franskmændene det arbejde, som Valls gør, og han er en af de få ministre, hvis popularitet stiger.

"Savner du Sarkozy?”, lød spørgsmålet i en meningsmåling, som blev gennemført i oktober 2012, og et stort flertal på 55 procent svarede nej. Så selv om Hollande bliver kritiseret, er der ikke noget folkeønske om at få forgængeren tilbage.

I det hele taget har den borgerlige opposition - og det vil reelt sige 
det store gaullistiske UMP-parti det svært. Det er rystet i sin grundvold efter at have mistet præsidentposten, regeringsansvaret og flertallet i Nationalforsamlingen. De borgerlige skal genopfinde sig selv i rollen som opposition, og det har udløst en bitter intern strid mellem forskellige fløje i partiet.

Nicolas Sarkozy meddelte allerede på valgaftenen, at han ville forlade toppolitik. Han lod det stå åbent, om han senere vil prøve at vende tilbage igen. Foreløbig er han trukket i løbetøjet og har været på lange ferier med sin familie. Han ytrer sig ikke om politik bortset fra en kraftig opfordring til det internationale samfund om at stoppe blodbadet i Syrien.

Straks han var ude af billedet, begyndte der en bitter arvefølgestrid. Sarkozy havde været partiformand, indtil han blev præsident i 2007. Han var dengang blevet afløst af Jean-François Copé, og egentlig skulle der ikke være nogen grund til, at Copé skulle forlade den post. Men knap var præsidentvalget $\mathrm{i}$ 2012 ovre, før Copé blev udfordret af tidligere premierminister, François Fillon, som så sig selv i formandsstolen.

\section{Forandringer nu}

"Le changement, c'est maintenant" (Forandring nu). Det var den parole, François Hollande gik til valg på i maj 2012. Og det var det jubelråb, der lød i gaderne den aften, han blev valgt. Nu rammer det ham i nakken som en boomerang, for ting tager tid. Det må han og hans regering erkende, men det kan franskmændene ikke vente på. De vil have synlige forandringer her og nu og ikke bare udsigt til skatteforhøjelser.

Regeringen har gennemført nogle populære beslutninger. Fx er ministrenes og præsidentens lønninger blevet sat ned med 30 pct., mindstelønnen, $S M I C$, sat op med to pct., og pensionsalderen, som Sarkozy havde sat op fra 60 til 62 år, er blevet ført tilbage til 60 år for dem, der er startet med at arbejde meget tidligt.

Men der mangler nogle markante socialistiske reformer. Præsidenten og hans regering har brugt det første halve år på at gøre boet op efter de borgerlige og fortælle franskmændene, hvor alvorlig den økonomiske situation er. Det har været 'operation sandheden', som Hollandes ekskone og tidligere præsidentkandidat, Ségolène Royal, udtrykte sig i et interview i Le Monde i slutningen af oktober. Nu forventer franskmændene, at 'drømmene' fra valgkampen bliver virkeliggjort, fortsatte hun og som eksempler nævnte hun en bankreform, en skattereform, en $\varnothing$ kologisk revolution og forbedringer af de unges fremtidsudsigter.

Connie Pedersen er journalist og cand. mag. i fransk. 